\title{
Soil Quality Refurbishment through Carbon Sequestration in Climate Change: A Review
}

\author{
Vijay Kumar ${ }^{1}$, K.R. Sharma ${ }^{2}$, Vikas Sharma², Vivak M. Arya ${ }^{2}$, Rakesh Kumar ${ }^{1}$, \\ V.B. Singh ${ }^{1}$, Bhav Kumar Sinha ${ }^{3}$ and Brinder Singh ${ }^{4}$ \\ ${ }^{1}$ Rainfed Research Sub-station for Sub-tropical fruits, Raya, Sher-e- Kashmir University of \\ Agricultural Sciences and Technology, Jammu - 181143 (J\&K), India \\ ${ }^{2}$ Division of Soil Science and Agricultural Chemistry FOA, Chatha, Sher-e- Kashmir University \\ of Agricultural Sciences and Technology, Jammu - 180009 (J\&K), India \\ ${ }^{3}$ Division of Plant Physiology FOA, Chatha, Sher-e- Kashmir University of Agricultural \\ Sciences and Technology, Jammu - 180009 (J\&K), India \\ ${ }^{4}$ Advanced Centre for Rainfed Agriculture, Dhiansar, Sher-e- Kashmir University of Agricultural \\ Sciences and Technology, Jammu - 180009 (J\&K), India \\ *Corresponding author
}

\section{Ke y w o r d s \\ Soil quality, \\ Carbon \\ sequestration, \\ Climate change, \\ Soil organic carbon. \\ Article Info \\ Accepted: \\ 12 April 2017 \\ Available Online: \\ 10 May 2017}

\section{A B S T R A C T}

Agricultural soils are capable of being a source or sink for atmospheric carbon dioxide depending upon the supervision practices and land use systems. Progressive enlarge in the concentration of green house gas (GHGs) since industrial era has created worldwide attention in identifying strategies to lessen concentration of these gases in the environment. Climate change has emerged a most important face up to not only for sustainable agriculture but also for human arrangement. Effect on climate change including global warming with its unhelpful impact on the living things on the earth is now global issue and appropriate strict day by day. Increase in the carbon dioxide concentration with the results of global warming in the atmosphere which is directly or indirectly related to climate change. The human activities that change the composition of global atmosphere adversely impact. In the systematic models and observations over the past one thousand years provide evidences that global warming may due to anthropogenic enhance in (GHG's) including that of carbon dioxide, methane, carbon monoxide. The increased atmospheric concentration of $\mathrm{CO}_{2}$ may power soil temperature, distribute erratic pattern of precipitation, evaporation and ensuing changes in the physico-chemical and biological properties in soil. Hence there is need has stress to reduce the concentration of carbon dioxide in the atmosphere and increase the carbon concentration in the soil through the process known as carbon sequestration. Carbon sequestration is an essential technology for the preservation of optimum $\mathrm{CO}_{2}$ level in the atmosphere, which in-turn grades in reducing the recent increase in atmospheric carbon dioxide, contributing to global warming. A substantial part of depleted soil organic carbon pool can be restored from side to side change of marginal lands into restorative land use systems, embracing of conservation tillage with cover crops and crop residue, mulch, nutrient cycling and use of organic manure and other systems for sustainable management of soil and water possessions. 


\section{Introduction}

Climate change is flattering a distressing issue today due to increasing amount of greenhouse gases (GHGs) in the atmosphere. It may perhaps be controlled by mitigating GHGs especially carbon dioxide, by sequestering carbon into soil and vegetative cover. The major GHGs are carbon dioxide $\left(\mathrm{CO}_{2}\right)$, methane $\left(\mathrm{CH}_{4}\right)$ and nitrous oxide $\left(\mathrm{N}_{2} \mathrm{O}\right)$. The concentration of $\mathrm{CO}_{2}, \mathrm{CH}_{4}$ and $\mathrm{N}_{2} \mathrm{O}$ in the environment since industrial uprising increased by 30,145 , and $15 \%$, respectively due to human activities (IPCC, 2007). Climate change will reflect in extreme weather events, spatial and inter-annual variability in weather events, which will negatively affect crop yield.

The $\mathrm{CO}_{2}$ is a sole GHG which traps long length wave radiation reflected from the earth's surface and doubtless the only one that has a major role in plant physiology. Increased stage of $\mathrm{CO}_{2}$ be capable of basis the stomata of the plants to close partially which reduces transpiration. $\mathrm{CO}_{2}$ causes 7.5 percent of the total global warming. Soil, vegetation and the ocean are considered potential sinks of carbon dioxide because of the large quantities of carbon dioxide currently sequestered in these pools and their capacities to continue taking up carbon dioxide. Photosynthesizing vegetation takes up carbon dioxide and sequesters it as biomass carbon in the terrestrial carbon pools of the soils. The restoration of soil quality through carbon sequestration is major concern for tropical soils. The accelerated decomposition of soil organic carbon due to agriculture resulting in loss of carbon to the atmosphere and its contribution to the greenhouse effect is a serious global problem.

\section{Soil quality}

The soil quality idea was evolved throughout the 1990s in response to increased global prominence on sustainable landuse systems and with a holistic focus emphasizing the sustainable soil management requires more than soil erosion control. Soil quality is distinct as the capacity of a soil to function within ecosystem boundaries to sustain biological productivity, preserve environmental quality, and encourage plant and human health (Doran and Parkin, 1994). Soil quality consideration and education are intended to provide a superior considerate and awareness that soil resources are truly living bodies with various soil characteristics and processes the stage essential ecosystem services (Table 1). The favourable effects of soil organic matter on the physical, chemical and thermal properties of the soil and on biological activity and thus in sustaining soil productivity and biodiversity may be seen as an important added-benefit over direct carbon mitigation techniques that would only physically store $\mathrm{CO}_{2}$ in the subsoil layer.

Soil organic carbon is the amounts of all in nature derived organic materials originate in the soil surface irrespective of its source, living status or stage of disintegration but apart from the aboveground segment of living plant. The organic carbon in provisions of its quantity and quality was essential to uphold the quality and efficiency soil.

\section{Carbon sequestration}

Soil C sequestration is necessary to improving soil quality, increasing use good organization of agronomic input, and advancing world food security. It is also necessary to improve water quality through filtration and denaturing of pollutants, and enhancing biodiversity by saving land for nature conservancy. Soil C sequestration is a low hanging fruit, and a bridge to the future until low-C or no-C fuel sources take effect. In the current greenhouse cause a created and great concern that has led to several studies on the qualities, kinds, giving out and behaviors of SOC 
(Velayutham et al., 2005). The organic matter content in soils varies significantly depending on climate soil type and landuse system. Decay of organic carbon was largely resolute by soil warmth and precipitation. Carbon sequestration is squeezing of carbon out of the atmosphere and its absorption and storage/uptake in a terrestrial or aquatic body. Capturing and storage carbon in biomass and soils in the agriculture, horticulture and forest sector has now gained prevalent reception as one potential greenhouse gas mitigation strategies.

Carbon sequestration in terrestrial ecosystems can be defined as the net removal of $\mathrm{CO}_{2}$ from the atmosphere and its storage into long-lived pools of carbon. The pools can be living, above ground biomass (e.g. Trees) products with a long, useful life created from biomass (e.g. lumber), living biomass in soils (e.g. roots and microorganisms) or recalcitrant organic and inorganic carbon in soils and deeper subsurface surroundings.

There are five important global carbon pools are presented in figure 1 and carbon flux among which oceanic pool $(38,000 \mathrm{pg})$ is the largest followed by geological pool $(5000 \mathrm{pg}$; $4000 \mathrm{pg}$ of coal pool and $500 \mathrm{pg}$ of each oil and gas) pedological pool (soil carbon pool, $2500 \mathrm{pg}$ ) biotic pool (560 pg) and the atmospheric pool (760 pg). The average atom of $\mathrm{C}$ spends about $5 \mathrm{yrs}$. in the atmosphere, 10 yrs. in vegetation (including trees), 35 yrs. in soil, and 100 yrs. in the sea (Lal, 2004).

Enhance density of $\mathrm{C}$ in the soil and depth of $\mathrm{C}$ in the profile, decrease decomposition of $\mathrm{C}$ and losses due to erosion are important measures to increase the soil organic carbon. Therefore, the strategy of $\mathrm{C}$ sequestration in soil and biota is an imperative option that requires a critical and purpose evaluation visa'-vis other technological options of stabilizing the atmospheric $\mathrm{CO}_{2}$ concentration.

\section{Impact of soil organic carbon dynamics:}

Impact of Soil texture

Impact of soil moisture

Impact of Fertilizer application

Impact of organic manure

Impact of soil temperature

Impact of soil salinity

Impact of vegetation

Impact of Tillage

\section{Impact of soil texture}

Soil texture was related percentage to the sand, silt and clay particles. Soils $\mathrm{pH}$ has a thoughtful effect on soil organic matter disintegration, even though it's precise mode of pressure has yet to be fully recognized. It was powerfully influences the expansion of bacteria, fungi and soil fauna and flora. Microbial movement at the time of extremely low or very high soil $\mathrm{pH}$ will persuade the rate of organic matter breakdown. The soil $\mathrm{pH}$ 8.7 carbon dioxide emissions was set up to be cheap by 18 per cent and at $\mathrm{pH} 10.0$ by 83 per cent compared to that at $\mathrm{pH} 7.0$ (Rao and Pathak, 1996).

\section{Impact of soil moisture}

Soil moisture was measured by different methods viz. Tensiometers, gravimetric and other techniques. Soil moisture content also affects organic matter in soil. These are the two factors are interdependent with the persuade of soil water-content being stronger at higher temperatures. Organic matter sharing across soil was prejudiced strongly by mean annual precipitation. The soil moisture content increased the results of increasing carbon dioxide evolution while the soil watercontent is subtropical for microbial movement. Periodic drying and wetting condition of the soil also increases $\mathrm{CO}_{2}$ development.

\section{Impact of fertilizer application}


In the fertilizers application usually increase the soil organic matter because the increased crop growth returns lager amounts of residues to the soil. Aerts and Toet (1997) suggested that increase in the supply of $\mathrm{NH}_{4}{ }^{+}$nitrogen leads to decrease in the decay of organic matter and loss of carbon. In tropical soils, application of fertilizers at suboptimal rates causes decline in the SOC pool.

\section{Impact of organic manure}

Soil organic carbon levels were moreover maintained or improved with the sufficient amount of manure. Application of several organic manures to minimizes soil erosion mediated by organic slaughter. However, climatic conditions in the dry and semi areas are tropics in favour of its departure as $\mathrm{CO}_{2}$. The manures as well as sewage sludge increase the soil respiration. Increase in the $\mathrm{CO}_{2}$ emission from the soil represented 21 per cent of carbon useful through sludge (Alvarez et al., 1999). The $\mathrm{CO}_{2}$ emission is directly connected to atmospheric pressure because it decreases triggers the release and emission of $\mathrm{CO}_{2}$.

\section{Impact of soil temperature}

Soil temperature is the one of the importance properties of soil organic dynamics conditions. It has enormous pressure on organic carbon exhaustion from soil. Predominance of temperature in the warm conditions under the tropics accelerates organic matter disintegration and defeat. At low temperature $\left(>0^{\circ} \mathrm{C}\right)$ plant growth is better than the rate of microbial putrefaction and organic matter may be mount up. At the time of above $25^{\circ} \mathrm{C}$, microbial decay/ putrefaction was superior to plant enlargement. Hence the organic matter manufacture was declines status. In the tropical Indian soils, the majority of which belongs to arid and semiarid areas are climate, infrequently display organic carbon levels exceeding 6.0 $\mathrm{gkg}^{-1}$ (Virmani et al., 1982).

\section{Impact of soil salinity}

The excessive amounts of salts have unfavourable effect on physical, chemical biological properties of soil. A progressive reduce in $\mathrm{CO}_{2}$ progression occurs with enhance in salinity of soil. Pathak and Rao (1998) was reported that the carbon mineralization was similar in soils up to the electrical conductivity (EC) value $26 \mathrm{dSm}^{-1}$, but gets severely reduced at higher EC

\section{Impact of vegetation}

The moist imperative factor influence the organic carbon levels in soil is the nature and quantity of vegetation. In the presence of crops/vegetations also influences carbon dynamics in soil. The bare land is the low organic carbon because these areas are scanty. The production of carbon dioxide is about 2 to 3 fold more in cropped soils compared to bare soils (Russell, 1973). Inside various crops also, there is variability in carbon dioxide production. The alluvial group of sandy loam soil, having $\mathrm{pH} 7.5$ and organic matter $6.6 \mathrm{~g} \mathrm{~kg}^{-1}$, planted to wheat and maize crops, $\mathrm{CO}_{2}$ emissions have been found as 36.7 and $61.7 \mathrm{~kg} \mathrm{CO}_{2} \mathrm{ha}^{-1}$ respectively.

\section{Impact of tillage}

The main reason of tillage is to supply the favourable soil environment for plant growth and vegetation development. It is one of the major factors responsible for reducing carbon stocks in soil. Soil organic matter is oxidized and when it is exposed by the air by tillage, resulting in a decline in organic matter (OM) content, unless additional $\mathrm{OM}$ is returned to the soil as crop residues, compost, or other means. Tillage disrupts the pores left by roots and microbial activity. Ploughing causes by rapid and lager changes in decomposition, exposing SOM previously protected inside the 
soil aggregates. During a tillage event, soil aggregates are broken down, increasing oxygen supply and surface area exposure of organic material. Hence, promotes the decomposition of organic matter. In contrast, conservation tillage favours organic carbon enrichment of soil (Lal, 1999).

\section{Effect of climate change on soil properties}

The quality of soil is slightly dynamic and can affect the sustainability and productivity of land use systems. It was last part product of soil degradative or conserving processes and is controlled by chemical, physical, and biological components of a soil. The enlarged atmospheric concentration of $\mathrm{CO}_{2}$ may operate soil temperature, distribution pattern of rainfall and evaporation and ensuing changes in soil moisture regimes. Soil quality was expressed capacity of a reference soil to function, within natural or managed ecosystem boundaries, to sustain plant and animal productivity, maintain or enhance water and air quality, and support human health and habitation. The soil physical, chemical and biological properties supply in order related to water and air movement through soil, as well as conditions affecting germination, root growth erosion processes. A lot of soil physical properties thus form the foundation of other chemical and biological mechanism might be due to further governed by climate, landscape location and land use systems. Soil fertility in simple terms is the ability of the soil to provide nutrient in fitting form and in right quality to the plants. The different soil physical, chemical and biological properties and some of the processes/mechanisms like weathering, mineralization, immobilization, nitrification, de-nitrification, biological nitrogen fixation, root microbes interactions and nutrient association influence soil fertility. Soil properties and processes that influence the availability of macro-micro nutrients to plant development depends on precipitation, temperature, soil carbon dioxide concentration, quantity of soil moisture and drought condition. Allen et al., (2011) reported that the key point of soil physical indicators in next of kin to climate change include bulk density, Particle density, porosity, structure, rooting depth, hydraulic conductivity, aggregate stability and water infiltration. In point of view with the physical parameters such as high intensity precipitation and agriculture is resolute by soil structure, as well as a range of chemical and biological properties (Dalal and Moloney, 2000). It is considered a useful soil health indicator since it is involved in maintaining important ecosystem functions in soil including organic carbon (C) accumulation, infiltration capacity, movement of water and root and microbial community activity, it can also be used to measure soil resistance to erosion and management changes (Lal, 2004). Porosity is refer as measure of the void spaces (macromicro) in a material as a fraction and pore size distribution provide a direct, quantitative estimate of the ability of a soil to store root zone water and air necessary for plant growth (Reynolds et al., 2002). The pore space/ porosity properties are strongly related to soil physical quality; bulk density and macro porosity are functions of pore volume, whereas soil porosity and water release characteristic directly influence a range of soil physical (Reynolds et al., 2009) indices including soil aeration aptitude plant available water capacity and relative field capacity.

Soil moisture deficit increases susceptibility to nutrient losses commencing the rooting zone through erosion which may be nutrients are carried to the roots by water in soluble or liquid form. Soil moisture scarcity decreases nutrient diffusion over short distances and the mass flow of water soluble nutrients such as nitrate, sulphate, calcium, magnesium and silicon over longer distance (Barber, 1995). 
The soil water and distribution which may reply to climate change, especially to variable and high intensity rainfall or drought events, and thus, management strategies such as the planting of cover crops, conservation tillage and incorporation of organic matter. The water infiltration and available water in soil may help in explanatory the impacts of severe precipitation and drought measures or severe erosion events (Salvador Sanchis et al., 2008). Decrease in both carbon and oxygen fluxes and nitrogen build up in root nodules under drought condition inhibits nitrogen fixation in legume crops (Athar and Ashraf, 2009). Soil moisture stress (Schimel et al., 2007) alters the masterpiece and movement of soil microbial communities which establish the $\mathrm{C}$ and $\mathrm{N}$ transformations that inspire soil fertility and nutrient cycling.

Soil erosion is dependent on three pillars like detachment, transportation and deposition. Soil particles detach from one place and transport from another place for deposit in soil particles. Surface erosion during intense rainfall actions is a significant source of soil nutrient loss in developing countries (Zougmore et al., 2009). High mobility in soil nitrate leaching following intense rainfall events is able to also a significant source of $\mathrm{N}$ loss in agriculture.

The differ in soil redox status under little oxygen which may lead to elemental toxicities like $\mathrm{Fe}, \mathrm{Mn}, \mathrm{Al}$ and $\mathrm{B}$ that diminish crop yields. Nitrogen is the significant losses occur under hypoxic conditions through denitrification as nitrate is used as an alternative electron acceptor by microbes in the absence of oxygen (Marschner, 1995). Nitrogen availability is important to soil fertility and $\mathrm{N}$ cycling is altered by human activity. Increased atmospheric $\mathrm{CO}_{2}$ concentrations global warming and changes in precipitation pattern are likely to affect $\mathrm{N}$ processes and $\mathrm{N}$ pools in forest ecosystems.

Higher temperature might increase the rate of microbial disintegration of organic matter unfavourably affecting soil fertility in the long run. The increase in root biomass ensuing from upper rates of photosynthesis could offset the effects. The higher temperature may perhaps accelerate the cycling of nutrients in the soil and more rapid root formation could promote more nitrogen fixation.

The soil warming which may increase nutrient uptake by 100- 300 per cent by enlarging the root surface area and increasing rates of nutrient diffusion and water influx. Emerging proof suggests that warmer temperatures have the potential to drastically affect nutrient status by altering plant phenology (Nord and Lynch, 2009). High temperature grades in increased soil salinization and volatilization losses of added nitrogen have recorded increased loss of ammonia with the increase in the temperature from 15 to $45^{0} \mathrm{C}$ which attributed to increased rate of urea hydrolysis and solubility of supplementary fertilizers to soils.

Temperature, rainfall and inherent soil properties such as parent material may have caused difference in $\mathrm{N}$ pool size through interaction with biota. The rainfall pattern of India is very erratic, space and high frequency distribution. Most of the area is undulating topography and low precipitation day by day. Climate change resolve directly affect carbon and nitrogen mineralization from side to side changes in temperature and soil moisture retention because also indirectly affect mineralization rates through changes in soil quality (Keller et al., 2004). 
Table.1 Indicators for soil quality

\begin{tabular}{|c|c|}
\hline Quality indicators & Relationship to soil health \\
\hline Soil organic matter (SOM) & $\begin{array}{l}\text { Soil fertility, structure, stability, nutrient retention, } \\
\text { soil erosion, and available water capacity }\end{array}$ \\
\hline \multicolumn{2}{|l|}{ Physical } \\
\hline Soil structure & $\begin{array}{l}\text { Retention and transport of water and nutrients, habitat } \\
\text { for microbes, and soil erosion }\end{array}$ \\
\hline Soil depth and rooting & $\begin{array}{l}\text { Estimate of crop productivity potential, compaction } \\
\text { and plow pan }\end{array}$ \\
\hline Infiltration and bulk density & Water movement, porosity and workability \\
\hline Water holding capacity & Water storage and availability \\
\hline Soil moisture & Moisture retention \\
\hline \multicolumn{2}{|l|}{ Chemical } \\
\hline $\mathrm{pH}$ & Nature soil acidity/ alkalinity and nutrient availability \\
\hline Electrical conductivity & Plant growth, microbial activity and salt tolerance \\
\hline $\begin{array}{l}\text { Available nitrogen }(\mathrm{N}) \text {, phosphorus } \\
(\mathrm{P}) \text {, and potassium }(\mathrm{K}\end{array}$ & $\begin{array}{l}\text { Plant available nutrients and potential for } \mathrm{N} \text { and } \mathrm{P} \\
\text { loss }\end{array}$ \\
\hline \multicolumn{2}{|l|}{ Biological } \\
\hline Microbial biomass carbon $(\mathrm{C})$ and $\mathrm{N}$ & $\begin{array}{l}\text { Microbial catalytic potential and repository for } \mathrm{C} \text { and } \\
\mathrm{N}\end{array}$ \\
\hline Potentially mineralizable $\mathrm{N}$ & Soil productivity and $\mathrm{N}$ supplying potential \\
\hline Soil respiration & Microbial activity measure \\
\hline
\end{tabular}

Fig.1 Estimates of the global pools and fluxes

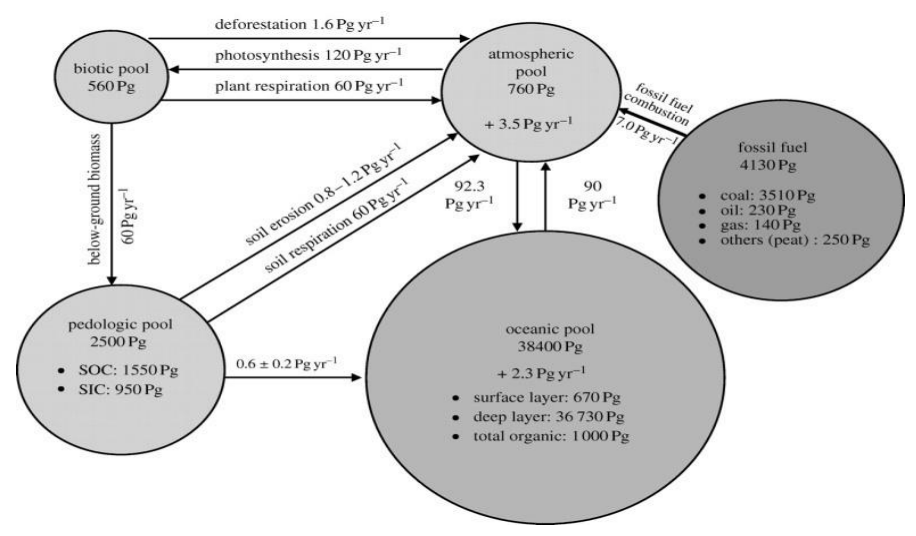

Executive strategies for carbon originated from plants and animal tissue that sequestration continue living at different stages of decomposition. Improved soil management

Soils are the largest carbon reservoir of the practices have exposed that systematic terrestrial carbon cycle. It stores large amount agriculture might be due to elucidation to of soil organic carbon (SOC), which is environmental issues in general and 
specifically for mitigating the greenhouse effect by rising soil carbon storage and successfully removing $\mathrm{CO}_{2}$ from the environment. Soil management techniques like increasing soil organic matter, reduced tillage, manuring, residue incorporation, improving soil biodiversity, aggregation, and mulches being play important roles in soil sequestration carbon.

\section{Conservation tillage}

Conservation agriculture (CA) is refer as minimal soil disturbance (no-till) and permanent soil cover (mulch) combined with rotations. CA is dependent three pillars like no- till, mulch and crop rotation. According to Food and Agricultural Organizations (FAO) of the United Nations, conservation agriculture is defined as a concept for resource saving of agricultural crop production that strives to achieve acceptable profits together with high and sustained production levels though concurrently conserving the environment and minimizing or eliminating strategy of the soil for crop production. It was involves an supply of modern agricultural technology to improve crop production, by maximization yields as well as maintain the health and integrity of the ecosystem distinct the traditional systems which mainly goal to maximize yields habitually at the cost of the environment (Dumanski et al., 2006). Conservation tillage involves reducing intensity and frequency of ploughing and leaving crop residues on the soil surface as mulch. This was the important strategy for enhancing SOC content and organic matter. Soil microbial biomass carbon was often found to be higher, but never lower, under zero tillage than under conventional tillage. Yet, $\mathrm{CO}_{2}$ evolution (basal respiration) was generally higher under conventional tillage than under zero tillage, ensuing in higher specific respiration under conventional tillage than under zero tillage. The superior additions but lower losses of labile $\mathrm{C}$ under zero tillage stand for that more $\mathrm{C}$ is sequestered in the soil in the zero-tillage system.CA improves agriculture by decreasing erosion, improving water infiltration, getting better soil surface aggregates, falling compaction through promotion of biological tillage, increasing organic matter, moderating soil temperatures, and suppressing weeds. It also helps in dropping costs of production, saves time, increases yield through timelier planting, decreases diseases and insect pests through encouragement of biological diversity and decrease greenhouse gas emissions (Hobbs, 2007). Thus, this system contributes less to atmospheric $\mathrm{CO}_{2}$ than conventional tillage, and soil organic matter accumulates more under zero tillage.

\section{Cover crops}

Cover crop is utilized of crops such as legumes and small grains for defence and soil development between periods of regular crop production. Cover crops recover carbon sequestration by enhancing soil structure and adding organic matter to the soil. Pulses append a significant quantity of organic carbon to soil since of their ability for atmospheric (Ganeshamurthy, 2009) nitrogen fixation, leaf shedding ability and better below-ground biomass. Venkatesh et al., (2013) reported that the study seven cropping cycles the changes in soil organic carbon pools due to the addition of pulses in an upland maize-based cropping system in Inceptisols of Indo-Gangetic plains. The outcome of the inclusion of pulses improved the total soil organic carbon content. It was more in surface soil $(0-20 \mathrm{~cm})$ and declined with increase in soil depth. Maize-wheatmungbean and pigeonpea-wheat systems resulted in significant enlarge of 11 and 10 percent respectively in total soil organic carbon, and 10 and 15 percent in soil 
microbial biomass carbon, respectively, as compared with a conventional maize-wheat system. The supply of crop residues along with farmyard manure at $5 \mathrm{Mg} \mathrm{ha}^{-1}$ and biofertilizers resulted in superior amounts of carbon fractions and higher carbon management index than in the in charge of and there commended inorganic fertilizers $(\mathrm{N}$, $\mathrm{P}, \mathrm{K}, \mathrm{S}, \mathrm{Zn}, \mathrm{B})$ treatment, particularly in the system where pulses were incorporated. The effectiveness of conservation tillage in SOC sequestration is enhanced by use of cover crops, such as clover and grains. Frequent use of pod type legumes and grasses in rotation with food crops is an important strategy to enhance SOC and soil quality (Entry et al., 1996). Hence, it may be concluded that cover crops helped to encourage biological soil tillage through their roots. The surface mulch provided food, nutrients and energy for earthworms, arthropods and micro organisms below ground that also biologically till soils.

\section{Crop rotation}

Crop rotation is a progression of crops grown in returning succession on the same area of land. It improves the soil structure and fertility of soil by irregular deep rooted and shallow rooted plants. A crop that leaches one type of nutrient from the soil is followed during the next growing season by a disparate crop that returns that nutrient to the soil or draw diverse ratio of nutrients. Changing the kind of crops grown can increase the level of soil organic matter. However, helpfulness of crop rotation depends on the kind of crops and crop rotation times. The chief component of crop rotation is refill of nitrogen through the use of green manure in series with cereals and other crops. Organic crop rotation include cultivation of deep rooted legumes which increase the carbon content in deeper soil layer by rhizo-deposition and deep root biomass. It also leads to more effective make use of of nitrogen and integrated livestock production. Different long term field experiments were conducted to compare crop sequencing with mono-cropping. Continuous maize cultivation with a legume-based rotation was studied by Gregorich et al., (2001). After 35 years, the difference between monoculture maize and the rotation was 20 tonne $\mathrm{C} \mathrm{ha}{ }^{-1}$. In adding together, the SOC present below the ploughed layer in the legume-based rotation appeared to be more biologically resistant, indicating the deep rooted plants were useful for increasing carbon storage at depth. Santos et al., (2011) observed that the basis of research done for 17 years that the forage-based rotations of semi-perennial alfalfa and annual rye grass for hay production contributed more to soil organic $\mathrm{C}$ sequestration than rotations based on cover crops. It was concluded that the roots, either in forage based or cover cropbased rotations, played a more relevant role in building up soil $\mathrm{C}$ stocks in no-till Ferralsol than shoot residues. Cropping systems provide an opportunity to produce more biomass $\mathrm{C}$ than in a monoculture system and to thus increase SOC sequestration. Chander et al., (1997) reported that the soil organic matter under different crop rotations for 6 years and found that inclusion of green manure crop of Sesbania aculeate in the rotation improved the soil organic matter status and microbial C increased from $192 \mathrm{mg}$ $\mathrm{kg}^{-1}$ soil in pearl millet wheat fallow rotation to $256 \mathrm{mg} \mathrm{kg}^{-1}$ soil in pearl millet wheat green manure rotation. Legume-based cropping systems might be due to increase crop productivity and soil organic matter levels, thereby enhancing soil quality, as well as having the additional benefit of sequestering atmospheric $\mathrm{C}$. The soil organic matter below the plough layer in soil under the legumebased rotation appeared to be in more biologically resistant form (i.e., higher aromatic $\mathrm{C}$ content) compared with that under monoculture. 


\section{Assimilation crop residue in soil}

Management of crop residues is of primary need in the incorporation of soil leads to increased soil organic matter levels. Amalgamation of rice and wheat crop residues helps in sequestering $\mathrm{C}$ in agricultural soils. Amalgamation of crop residues significantly increased soil organic $\mathrm{C}$ content in a long term field experiment conducted in rice-wheat cropping system (Singh et al., 2000). Cereal crop residues with high $\mathrm{C}$ : $\mathrm{N}$ ratio leaves more $\mathrm{C}$ in soil for exchange to soil organic matter. The problem of on-farm burning of crop residues has intensified in recent years due to use of combines for harvesting and high cost of labours in removing the crop residues by conventional methods (NAAS, 2012). Burning disturbs the microbial population in the soil, leads to moisture defeat and increases the $\mathrm{pH}$ of soil due to production of ash, which contains $\mathrm{Ca}, \mathrm{Mg}$ and $\mathrm{K}$ ions. Left crop residue in the field is another practice which will have an important impact on the sequestration of carbon. (Lal, 1997) reported that the annual production of crop residue in the world is approximate to be about $3.4 \times 10^{9}$ tonnes because 15 percent of the $\mathrm{C}$ present in the residues can be converted to passive organic carbon fraction, this may lead to $\mathrm{C}$ sequestration of $0.2 \times 10^{15}$ g/year. Crop residue below-ground residues and root turnover represented direct inputs into the soil organization, and as such had the potential to make major contributions to SOM stocks (Sanderman et al., 2010). The use of crop residues as mulches has been established useful as it reduces maximum soil temperature and conserves water. Direct drilling of wheat into rice residue using happy seeder is a good quality agronomic practice for wheat, serving to limit the gradual lessening of soil organic matter and at the same time improving soil health. Happy seeder allows zero-till sowing of wheat with rice residue as surface mulch, at the same time as maintaining yield, reduces tillage costs and time saving, avoids the need for burning (Singh and Sidhu, 2014).

\section{Nutrient management}

Nutrient management is using of crop residue and judicious use of fertilizer in the field. On a long-term field experiment increased crop yield and organic matter returned to the soil with judicious fertilizer relevance outcome in superior SOC content and biological motion than under embarrassed conditions (absence of fertilizers). The studies and concluded that fertility management practices can enhance the SOC content at the rate of $50-150 \mathrm{~kg} \mathrm{ha}^{-1}$ $\mathrm{yr}^{-1}$ (Lal et al., 1998). Enhancing the nitrogen doses increases quantity of organic matter in soil and phosphorus fertilizer also has a beneficial impact on soil organic $\mathrm{C}$. Integrated nutrient management through farmyard manure, green manure and crop residues is advantageous in increasing organic matter in soil.

\section{Land use change}

The land use pattern of India indicates that cropland dominates and followed by forestland. The land use, land use change and forestry sector (LULUCF) includes emissions and removals from changes mostly in forestland, cropland and pasturelands, which sequesters 177 million tonne of $\mathrm{CO}_{2}$ (NAAS, 2014). This sector plays an important role in modifiable the emission profile from the farming sector and provides avenues for increasing the sink. Degraded soils converting under agriculture and other land uses into forests and perennial land use can enhance the SOC pool. The scale and rate of SOC sequestration with afforestation depends on climate, soil type, species and nutrient management. Carbon emissions attributed to changes in land use and land cover, can 
significantly affect management strategies that are intended to enhance carbon sequestration and decrease the atmospheric $\mathrm{CO}_{2}$ concentration (Lal, 2001). Mann (1986) also calculated the $\mathrm{CO}_{2}$ emissions associated with crop production on several additional land brought into production, as well as emissions from the change in land use and finished that for the initial 20 years following conversion, changing from non-cropland (i.e. grassland or forest) to cropland was believed to release $750 \mathrm{~kg} \mathrm{C}$ per ha per year. Therefore, in such cases, agroforestry may be another option of conserving soil and improving the SOC pool.

\section{Soil amendments}

Soil amendment is any materials that organic and inorganic to improve the soil fertility and increased in carbon sequestration. Soil amendments are also left over crop residues from processes that have favourable properties when added to soil. Generally used amendments comprise municipal bio-solids, animal manures and litters, wood ash, neutralizing lime products, composted biosolids, soil ash, mulches, composted food scraps and a variety of composted agricultural by-products. By totting up these to soil helps in restoring soil quality by balancing $\mathrm{pH}$, adds organic matter, improves water holding capacity, re-establishes microbial communities, and decreased compaction in soil. Separately from improving soil characteristics, soil amendment application, prevent $\mathrm{CO}_{2}$ and methane emissions that would otherwise occur when industrial by products (i.e. bio-solids and other soil amendments) are feeling like.

In conclusion carbon sequestration is very much related to the soil and its management system. Zero or minimum tillage combined with crop residue maintenance on the soil surface helps in sequester carbon, improves water use efficiency and decrease fossil fuel consumption. The energetic processes that manipulate soil quality are complex, and they activate through time at various locations and situations. Soil organic matter is both source of carbon discharge and a sink for carbon appropriation. Cultivation and tillage could be decrease and alteration the distribution of SOC as an appropriate crop rotation might be due to boost or maintain the quantity and quality of soil organic matter, the improvement of soil physical, chemical and biological properties. The go back of crop residues and the application of manure and fertilizers which might be due to all contribute to an increase in soil nutrients and SOC content because require to be combined into a management system for more improvement. Due to limited availability of oxygen decomposition is slow and incorporation of residue into the soil leads to early disintegration and let loose of $\mathrm{CO}_{2}$ hence it should be avoided. Crop rotation contributes to carbon sequestration since it can increase the rate of build up of SOC at diverse depths in the soil profile, as various crop species have different root depths. The negative important impacts of monoculture are predisposed by kind of crop with fauna insolvency, a greater than before number of crop pests, a refuse in activities of dehydrogenase and phosphatase, and increased levels in the soil of phenolic acids. SOC was conserved by with crop rotations with reduced tillage rate of recurrence and flourishes of chemical fertilizers, crop residues and manure. There is require for obtaining the more data on long term effects of different tillage systems on carbon and nitrogen mineralization and immobilization in diverse field situations. The matter concerned in understanding the soil quality and soil systems for agricultural sustainability have to be more holistic, and it needs further investigation. It helps in improving soil fertility that stimulates plant escalation which 
ultimately increases the biomass foremost to higher $\mathrm{CO}_{2}$ utilization.

\section{References}

Aerts, R. and Toet, S. 1997. Nutritional controls on carbon dioxide and methane emission from carex-dominated peat soils. Soil Bio Biochem., 29(11-12): 1683-1690.

Allen, D.E., Singh, B.P. and Dalal, R.C. 2011. Soil health indicators under climate change: A review of current knowledge. In: Soil health in climate change, Singh B P, Cowie A L and Chan K Y. Ed.), Soil Biol., 29, Springer-Verlag Berlin Heidelberg.

Alvarez, R., Alconada, M. and Lavado, R. 1999. Sewage sludge effects on carbon dioxide-carbon production from a desurfaced soil. Comm. Soil Sci. Plant Anal., 30(13-14): 1861-1866.

Athar, H.R. and Asharf, M. 2009. Strategies for crop improvement against salinity and drought stress: An overview. In: Athar, H.R. and Ozturk, M.. Ed.. Salinity and water stress: improving crop efficiency. Springer, New York, 1$16 \mathrm{pp}$.

Barber, S.A. 1995. Soil nutrient bioavailability: a mechanistic approach. 2nd Ed., Wiley, New York.

Chander, K., Goyal, S., Mundra, M.C. and Kapoor, K.K. 1997. Organic matter, microbial biomass and enzyme activity of soils under different crop rotations in the tropics. Bio Fert. Soils, 24(3): 306310.

Dalal, R.C. and Monoley, D. 2000. Sustainability indicators of soil health and biodiversity. In: Management for sustainable ecosystems. Hale P, Petrie A, Monoley D and Sattler P. Ed.), Centre for Conservation Biology, Brisbane, 101-108pp.

Doran, J.W. and Parkin, T.B. 1994. Defining soil quality for a sustainable environment. In: Soil Science Society of America Special Publication No. 35 J.W. Doran, D.C. Coleman, D.F. Bezdicek and B.A. Stewart. Eds). Soil Science Society of America, Madison, Winconsin. 3-21pp.

Dumanski, J., Peiretti, R., Benites, J.R., Mc Garry, D. and Pieri, C. 2006. The paradigm of conservation agriculture. Proc. World Assoc. Soil Water Conserv., P1 58-64.

Entry, J.A., Mitchell, C.C. and Backman, C.B. 1996. Influence of management practices on soil organic matter, microbial biomass and cotton yield in Alabama's "old rotation". Bio Fert. Soils, 23(4): 353-358.

Ganeshamurthy, A.N. 2009. Soil changes following long-term cultivation of pulses. J. Agric. Sci., 147: 699706.

Gregorich, E.G., Drury, C.F. and Baldock, J.A. 2001. Changes in soil carbon under long-term maize in monoculture and legume-based rotation. Can. J. Soil Sci., 81: 21-31.

Hobbs, P.R. 2007. Conservation agriculture: what is it and why is it important for future sustainable food production. $J$. Agric. Sci., 145: 127-137.

IPCC. 2007. Intergovernmental Panel on Climate Change 2007, the Fourth Assessment Report.

Keller, K., Bolker, B.M. and Bradford, D.F. 2004. Uncertain climate thresholds and optimal economic growth. J. Env. Eco Mgmt., 48(1): 732-741.

Lal, R. 1997. Residue management conservation tillage and soil restoration for mitigating greenhouse effect by $\mathrm{CO}_{2}$ - enrichment. Soil Till Res., 43: 81107.

Lal, R. 1999. Soil management and restoration for carbon sequestration to mitigate the accelerated greenhouse effect. Prog. Env. Sci., 1(4): 307-326. 
Lal, R. 2001. The potential of soil carbon sequestration in forest ecosystem to mitigate the greenhouse effect. In: Lal R.. Ed.), Soil Carbon Sequestration and the Greenhouse Effect. Soil Science Society of America Special Publication, 57 Madison, WI.

Lal, R. 2004. Soil carbon sequestration to mitigate climate change. Geoderma, 123: 1-22.

Lal, R., Henderlong, P. and Flowers, M. 1998. Forages and row cropping effects on soil organic carbon and nitrogen contents. In: Lal R, Kimble J M, Follett $\mathrm{R} \quad \mathrm{F}$ and Stewart B A. Ed.). Management of carbon sequestration in soil. CRC Press, Boca Raton F L 365379pp.

Mann, L.K. 1986. Changes in soil carbon storage after cultivation. Soil Sci., 142: 279-288.

Marchner, H. 1995. Mineral nutrition of higher plants. Academic, San Diego.

NAAS. 2012. Management of Crop Residues in the Context of Conservation Agriculture. Policy Paper No. 58, National Academy of Agricultural Sciences, New Delhi. 12 p.

NAAS. 2014. Carbon Economy in Indian Agriculture. Policy Paper No. 69, National Academy of Agricultural Sciences, New Delhi: 19 p.

Nord, E.A. and Lynch, J.P. 2009. Plant phenology: a critical controller of soil resource acquisition. J. Exp. Bot., 60(7): 1927- 1937.

Pathak, H. and Rao, D.L.N. 1998. Carbon and nitrogen mineralization from added organic matter in saline and alkali soils. Soil Biol. Biochem., 30(6): 695-702.

Rao, D.L.N. and Pathak, H. 1996. Ameliorative influence of organic matter on biological activity of saltaffected soils. Arid Soil Res. Rehabilit., 10(4): 311-319.

Reynolds, W.D., Bowman, B.T., Drury, C.F.,
Tan, C.S. and Lu, X. 2002. Indicators of good soil physical quality: density and storage parameters. Geoderma, 110(12): 131-146.

Reynolds, W.D., Drury, C.F., Tan, C.S., Fox, C., and Yang, X.M. 2009. Use of indicators and pore volume-function characteristics to qualify soil physical quality. Geoderma, 152(3-4): 252-263.

Russell, E.W. 1973. Soil conditions and plant growth, 10th Ed. Longmans. London. United Kingdom, 403-405pp.

Salvador Sanchis, M.P., Torri, D., Borselli, L. and Poesen, J. 2008. Climate effects on soil erodiblity. Earth Surface Processes and Landforms, 33(7): 1082-1097.

Sanderman, J., Farquharson, R. and Baldock, J. 2010. Soil carbon sequestration potential: A review for Australian agriculture. A report prepared for the Department of Climate Change and Energy Efficiency CSIRO National Research Flagships.

Santos, N., Jeferson Dieckow Cime lio, Bayer Molin, R., Nerilde Favaretto Volnei Pauletti and Jonatas Thiago Piva. 2011. Forages cover crops and related shoot and root additions in no-till rotations. to C sequestration in a subtropical Ferralsol. Soil Till. Res., 111: 208-218.

Schimel, J., Balser, T.C. and Wallenstein, M. 2007. Microbial stress response physiology and its implications for ecosystem function. Ecol., 88(6): 13861394.

Singh, Y. and Sidhu, H.S. 2014. Management of Cereal Crop Residues for Sustainable Rice-Wheat Production System in the Indo-Gangetic Plains of India. Proc. Indian Natn. Sci. Acad., 80: 95-114.

Singh, Y., Singh, B., Meelu, O.P. and Khind, C.S. 2000. Long term effects of organic manuring and crop residues on the productivity and sustainability of ricewheat cropping system of North-West India. In: I P Abrol, K F Bronson, J M 
Duxbury and R K Gupta. Ed.. Long term soil fertility experiments in ricewheat cropping systems, RWC Paper series, 6, New Delhi. 149-162pp.

Velayutham, M., Pal, D.K. and Bhattacharyya, T. 2005. In: Global climate change and tropical ecosystem. Lewis Publishers, Boca Raton, FL. 71$96 \mathrm{pp}$.

Venkatesh, M.S., Hazra, K.K., Ghosh, P.K., Praharaj, C.S. and Kumar, N. 2013. Long-term effect of pulses and nutrient management on soil carbon sequestration in Indo-Gangetic plains of India. Can. J. Soil Sci., 93: 127-136.

Virmani, S.M., Sahrawat, K.L. and Burford, J.R. 1982. In: Vertisols and rice soils of the tropics. Trans. 12th International Congress of Soil Science, New Delhi 80-93pp.

Zougmore, R., Mando, A. and Stroosnijider, L. 2009. Soil nutrient and sediment loss as affected by erosion barriers and nutrient source in semi arid burkina Faso. Arid Land Res. Mgmt., 23: 85101.

\section{How to cite this article:}

Vijay Kumar, K.R. Sharma, Vikas Sharma, Vivak M. Arya, Rakesh Kumar, V.B. Singh, Bhav Kumar Sinha and Brinder Singh. 2017. Soil Quality Refurbishment through Carbon Sequestration in Climate Change: A Review. Int.J.Curr.Microbiol.App.Sci. 6(5): 1210-1223. doi: https://doi.org/10.20546/ijcmas.2017.605.131 